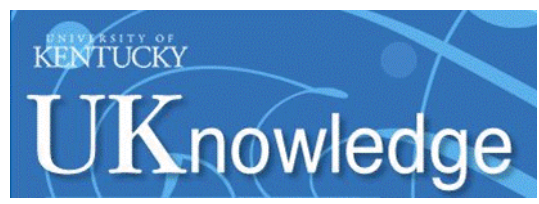

University of Kentucky

UKnowledge

\title{
Short-term Response of Soil Iron to Nitrate Addition
}

Christopher J. Matocha

University of Kentucky, cjmato2@uky.edu

Mark S. Coyne

University of Kentucky, mark.coyne@uky.edu

Follow this and additional works at: https://uknowledge.uky.edu/pss_facpub

Part of the Plant Sciences Commons

Right click to open a feedback form in a new tab to let us know how this document benefits you.

\section{Repository Citation}

Matocha, Christopher J. and Coyne, Mark S., "Short-term Response of Soil Iron to Nitrate Addition" (2007). Plant and Soil Sciences Faculty Publications. 11.

https://uknowledge.uky.edu/pss_facpub/11

This Article is brought to you for free and open access by the Plant and Soil Sciences at UKnowledge. It has been accepted for inclusion in Plant and Soil Sciences Faculty Publications by an authorized administrator of UKnowledge. For more information, please contact UKnowledge@lsv.uky.edu. 


\section{Short-term Response of Soil Iron to Nitrate Addition}

Digital Object Identifier (DOI)

http://dx.doi.org/10.2136/sssaj2005.0170

Notes/Citation Information

Published in Soil Science Society of America Journal, v. 71, no. 1, p. 108-117.

The copyright holder has granted the permission for posting the article here. 


\section{Short-term Response of Soil Iron to Nitrate Addition}

\author{
C. J. Matocha* \\ Department of Plant and Soil Science \\ Univ. of Kentucky \\ N-122 Agricultural Science Center-North \\ Lexington, KY 40546-0091
}

\section{S. Coyne}

Department of Plant and Soil Science Univ. of Kentucky

N-122 Agricultural Science Center-North Lexington, KY 40546-009
The inhibition of soil Fe(III) reduction by fertilizer $\mathrm{NO}_{3}{ }^{-}$applications is complex and not completely understood. This inhibition is important to study because of the potential impact on soil physicochemical properties. We investigated the effect of adding $\mathrm{NO}_{3}{ }^{-}$to a moderately well-drained agricultural soil (Sadler silt loam) under Fe(III)-reducing (anoxic) conditions. Stirred-batch experiments were conducted where $\mathrm{NO}_{3}{ }^{-}$was added $(0.05$ and $1 \mathrm{mM})$ to anoxic slurries and changes in dissolved $\mathrm{Fe}(\mathrm{II})$ and $\mathrm{Fe}(\mathrm{III})$, oxalate-extractable $\mathrm{Fe}(\mathrm{II})$, and dissolved $\mathrm{NO}_{3}{ }^{-}$were monitored as a function of time. Addition of $1 \mathrm{mM} \mathrm{NO}_{3}{ }^{-}$inhibited $\mathrm{Fe}(\mathrm{II})$ production sharply with reaction time, from $10 \%$ after $1 \mathrm{~h}$ to $85 \%$ after $24 \mathrm{~h}$. The duration of inhibition in $\mathrm{Fe}(\mathrm{II})$ production was closely related to the presence of available $\mathrm{NO}_{3}{ }^{-}$, suggesting preferential use of $\mathrm{NO}_{3}{ }^{-}$by nitrate reductase enzyme. Active nitrate reductase was confirmed by the fivefold decline in $\mathrm{NO}_{3}{ }^{-}$reduction rates in the presence of tungstate $\left(\mathrm{WO}_{4}{ }^{2-}\right)$, a well-known inhibitor of nitrate reductase. In addition, $\mathrm{NO}_{3}{ }^{-}$-dependent $\mathrm{Fe}$ (II) oxidation was observed to contribute to the inhibition in Fe(II) production. This finding was attributed to a combination of chemical reoxidation of $\mathrm{Fe}(\mathrm{II})$ by $\mathrm{NO}_{2}{ }^{-}{ }^{-}$and $\mathrm{NO}_{3}{ }^{-}$-dependent $\mathrm{Fe}$ (II) oxidation by autotrophic bacteria. These two processes became more important at a greater initial oxalate- $\mathrm{Fe}(\mathrm{II}) / \mathrm{NO}_{3}{ }^{-}$concentration ratio. The inhibitory effects in $\mathrm{Fe}(\mathrm{II})$ production were short-term in the sense that once $\mathrm{NO}_{3}{ }^{-}$was depleted, $\mathrm{Fe}(\mathrm{II})$ production resumed. These results underscore the complexity of the coupled N-Fe redox system in soils.

Abbreviations: AAS, atomic absorption spectrometry; HIV, hydroxy-interlayered vermiculite.
$I^{n}$ $\mathrm{n}$ oxic soil environments, $\mathrm{Fe}(\mathrm{III})$ is present in $\mathrm{Fe}(\mathrm{III})$ (hydr)oxide minerals or phyllosilicate clays. The importance of microbial Fe(III) reduction to $\mathrm{Fe}(\mathrm{II})$ is in part due to its impact on soil physicochemical properties (Stucki et al., 1996; Favre et al., 2002) and its role in organic C oxidation (Lovley, 2000). The reduction of Fe(III) can be inhibited by the presence of $\mathrm{NO}_{3}{ }^{-}$. This inhibition alters the speciation of transition metals such as $\mathrm{Zn}$ that adsorb to Fe(III) (hydr)oxide surfaces (Cooper et al., 2000). Four hypotheses have been proposed to explain the inhibitory mechanism of $\mathrm{NO}_{3}{ }^{-}$on $\mathrm{Fe}(\mathrm{III})$ reduction. The first hypothesis is based on thermodynamic arguments. The classical model of terminal electron-accepting processes that occur during microbial degradation of organic $\mathrm{C}$ predicts a sequence of oxidant consumption to follow the order of $\mathrm{O}_{2}$ reduction, $\mathrm{NO}_{3}{ }^{-}$reduction, $\mathrm{MnO}_{2}$ reduction, $\mathrm{Fe}(\mathrm{III})$ (hydr) oxide reduction, $\mathrm{SO}_{4}{ }^{2-}$ reduction, and $\mathrm{CH}_{4}$ production (McBride, 1994). Nitrate, due to its position on the redox ladder, increases the redox potential $\left(\mathrm{E}_{\mathrm{H}}\right)$ beyond where $\mathrm{Fe}(\mathrm{III})$ reduction occurs $\left(\mathrm{E}_{\mathrm{H}}=200-400 \mathrm{mV}\right)$, thereby preventing Fe(II) release (Ponnamperuma and Castro, 1964; Ponnamperuma, 1972). This view appears to be an oversimplification. It assumes that the more thermodynamically favorable reduction of $\mathrm{NO}_{3}{ }^{-}$excludes $\mathrm{Fe}(\mathrm{III})$ reduction, despite favorable thermodynamics in the latter reaction and variable reactivities of Fe(III) (hydr)oxide minerals (Roden, 2003). Furthermore, Munch and Ottow (1980) have pointed out that the activity of

Soil Sci. Soc. Am. J. 71:108-117

doi:10.2136/sssaj2005.0170

Received 1 June 2005

*Corresponding author (cjmato2@uky.edu).

(c) Soil Science Society of America

677 S. Segoe Rd. Madison WI 53711 USA microbial reductases are more important than $\mathrm{E}_{\mathrm{H}}$ in governing $\mathrm{Fe}(\mathrm{III})$ reduction.

The second hypothesis proposed by Ottow (1970) claimed that nitrate reductases, enzymes produced by bacteria to catalyze heterotrophic reduction of $\mathrm{NO}_{3}{ }^{-}$to $\mathrm{NO}_{2}{ }^{-}$, preferentially transfer electrons to $\mathrm{NO}_{3}{ }^{-}$rather than Fe(III). Sorensen (1982) suggested that nitrate reductase inhibited $\mathrm{Fe}(\mathrm{III})$ reduction because treatment of sediment slurries with $0.2 \mathrm{mMNO}_{3}{ }^{-}$halted $\mathrm{Fe}(\mathrm{II})$ accumulation. After the $\mathrm{NO}_{3}{ }^{-}$supply was depleted, $\mathrm{Fe}(\mathrm{III})$ reduction resumed. Munch and Ottow (1980) pointed out that the presence of nitrate reductase is what leads to suppressed $\mathrm{Fe}(\mathrm{II})$ formation by $\mathrm{NO}_{3}{ }^{-}$under anoxic conditions. Nitrate reductases contain Mo in their active site that cycles between $+4\left(\mathrm{~d}^{2}\right)$ and $+6\left(\mathrm{~d}^{0}\right)$ oxidation states during reduction of $\mathrm{NO}_{3}{ }^{-}$to $\mathrm{NO}_{2}{ }^{-}$(Hille, 1996). Addition of $\mathrm{WO}_{4}{ }^{2-}$ inactivates the enzyme by substitution for Mo (Scott et al., 1979; Smith, 1983). It may be possible to verify this hypothesis by adding $\mathrm{WO}_{4}{ }^{2-}$ to soil slurries. To our knowledge, the effect of $\mathrm{WO}_{4}{ }^{2-}$ on Fe(III) reduction is not known.

The third hypothesis involves concomitant reduction of $\mathrm{NO}_{3}{ }^{-}$and $\mathrm{Fe}$ (III) coupled to chemical reoxidation of $\mathrm{Fe}(\mathrm{II})$ by $\mathrm{NO}_{2}{ }^{-}$. In laboratory incubations of field soils, aquifer materials, and pure cultures, reduction of $\mathrm{NO}_{3}{ }^{-}$by nitrate reductase occurs simultaneously with Fe(III) reduction (Komatsu et al., 1978; Obuekwe et al., 1981; DiChristina, 1992; Broholm et al., 2000; Cooper et al., 2003). Under the scenario of concomitant $\mathrm{Fe}(\mathrm{III})$ and $\mathrm{NO}_{3}{ }^{-}$reduction, intermediates generated such as $\mathrm{NO}_{2}{ }^{-}$can transiently accumulate and chemically oxidize $\mathrm{Fe}(\mathrm{II})$ to Fe(III), leading to no net Fe(III) reduction (Lovley, 2000). This process has been proposed to occur in agricultural soil slurries and pure cultures (Komatsu et al., 1978; Obuekwe et al., 1981). However, DiChristina (1992) observed that neither $\mathrm{NO}_{3}{ }^{-}$nor $\mathrm{NO}_{2}{ }^{-}$behaved as chemical oxidants of Fe(II), but the inhibition was due to $\mathrm{NO}_{2}{ }^{-}$blocking electron transport to 
Fe(III) in pure cultures of Shewanella putrafaciens. The latter study was performed in the absence of mineral surfaces and $\mathrm{Fe}(\mathrm{III})$ salts were used as a source of Fe. In soil environments, it is conceivable that $\mathrm{Fe}$ (II) generated from $\mathrm{Fe}$ (III) reduction coordinates to mineral surfaces in an inner sphere complex or reprecipitates as a secondary $\mathrm{Fe}(\mathrm{II})$ mineral phase (Fredrickson et al., 1998; Zachara et al., 2002). The Fe(II) in these coordination environments, where $\mathrm{O}$ is the ligating atom, could be more reactive toward $\mathrm{NO}_{2}{ }^{-}$because the reduction potential is lowered for the Fe(III)-Fe(II) half-reaction (Luther et al., 1992). In fact, Sorensen and Thorling (1991) found that Fe(II) adsorbed on lepidocrocite $\left[\gamma-\mathrm{FeOOH}_{(s)}\right]$ reduced $\mathrm{NO}_{2}{ }^{-}$much more rapidly than dissolved, hexaaquo Fe(II).

The fourth hypothesis involves autotrophic bacteria that can reduce $\mathrm{NO}_{3}^{-}$to $\mathrm{N}_{2}$ with concomitant $\mathrm{Fe}(\mathrm{II})$ oxidation. These bacteria have been identified in European freshwater sediments (Straub et al., 1996), activated sludge treatment plants (Nielsen and Nielsen, 1998), urban lake sediments (Senn and Hemond, 2002), and anoxic rice paddy soil slurries (Klüber and Conrad, 1998). Dissolved Fe(II) and solid $\mathrm{Fe}(\mathrm{II})$ in minerals such as siderite $\left[\mathrm{FeCO}_{3(\mathrm{~s})}\right]$ and magnetite $\left[\mathrm{Fe}_{3} \mathrm{O}_{4(\mathrm{~s})}\right]$ are capable of being used by bacteria during $\mathrm{NO}_{3}{ }^{-}$ reduction (Straub et al., 1996; Weber et al., 2001). In addition, $\mathrm{Fe}(\mathrm{II})$ associated with phyllosilicate minerals has emerged as a suitable electron donor for autotrophs during $\mathrm{NO}_{3}{ }^{-}$reduction (Shelobolina et al., 2003).

Most of these studies evaluating the inhibitory effect of $\mathrm{NO}_{3}{ }^{-}$on $\mathrm{Fe}(\mathrm{III})$ reduction used pure cultures and synthetically prepared Fe(III) minerals or Fe(III) salts. This is due to the complexities associated with soil, where the inhibitory effect may be controlled in complex ways by these various processes that may compete with one another. The present study was undertaken to analyze the effect of $\mathrm{NO}_{3}{ }^{-}$addition on $\mathrm{Fe}(\mathrm{II})$ production in field soil subjected to anoxic [Fe(III)-reducing] conditions using stirred-batch experiments in the laboratory. Specifically, the objectives were to determine whether the effect of $\mathrm{NO}_{3}{ }^{-}$was due to: (i) competitive inhibition by nitrate reductase; (ii) concomitant reduction of $\mathrm{Fe}(\mathrm{III})$ and $\mathrm{NO}_{3}{ }^{-}$reduction linked to chemical reoxidation of biogenic $\mathrm{Fe}$ (II) by $\mathrm{NO}_{2}{ }^{-}$; or (iii) $\mathrm{NO}_{3}{ }^{-}$-dependent $\mathrm{Fe}(\mathrm{II})$-oxidizing autotrophic bacteria. Changes in different pools of Fe [dissolved Fe(II), oxalate-extractable $\mathrm{Fe}(\mathrm{II})$, and dissolved $\mathrm{Fe}(\mathrm{III})$ ] and dissolved $\mathrm{NO}_{3}{ }^{-}$were monitored as a function of time and compared with controls (no $\mathrm{NO}_{3}{ }^{-}$). This will provide insight into the relative importance of the hypothetical pathways enumerated above. If the nitrate reductase competitive model is the main mechanism for inhibiting Fe(II) production, then addition of $\mathrm{WO}_{4}{ }^{2-}$ should curtail the inhibition. Tungstate-treated soil slurries would also allow evaluation of the contribution of autotrophic $\mathrm{Fe}(\mathrm{II})$ oxidation coupled to $\mathrm{NO}_{3}{ }^{-}$reduction. This work will provide a better understanding of what happens when $\mathrm{NO}_{3}{ }^{-}$is surface applied as $\mathrm{N}$ fertilizer under $\mathrm{Fe}(\mathrm{III})$ reducing conditions.

\section{MATERIALS AND METHODS Soil Collection}

A Sadler silt loam (fine-silty, mixed, mesic Glossic Fragiudalf) was collected from the surface $(0-5 \mathrm{~cm})$ Ap horizon of a field site in Christian County, Kentucky. The soil developed in loess over sandstone parent materials and is moderately well drained (Karathanasis, 1987). Soil samples were taken with a cylindrical probe $2.0 \mathrm{~cm}$ in diameter from multiple soil cores (8-10) and placed in polyethylene bags. Preliminary extractions using oxalate and ferrozine revealed that $\mathrm{Fe}(\mathrm{II})$ was present at the time of sampling. Thus, the soil samples were immediately quick-frozen in the field using liquid $\mathrm{N}_{2}$ to preserve the $\mathrm{Fe}$ (II) oxidation state and placed on dry ice during transport back to the laboratory. Samples were thawed, homogenized, carefully sieved to $<2 \mathrm{~mm}$, and stored under $\mathrm{Ar}$ in an $\mathrm{O}_{2}$-free glove box (Coy Laboratory Products, Grass Lake, MI).

\section{Soil Characterization}

Part of the soil was removed from the anoxic chamber for characterization. Soil was separated into the following soil particle size separates: sand (2000-50 $\mu \mathrm{m})$, silt (50-2 $\mu \mathrm{m})$, and clay $(<2 \mu \mathrm{m})$. Fractionation procedures followed those of Jackson (1974), using $\mathrm{NaHCO}_{3}$ to disperse the soil and omitting chemical pretreatment steps. Chemical extractions were performed in triplicate on the whole soil and particle size fractions to quantify poorly crystalline Fe(III) (hydr)oxides (acid ammonium oxalate extraction, Phillips and Lovley, 1987), and total reducible Fe(III) (hydr)oxides (dithionite-citrate-bicarbonate extraction, Mehra and Jackson, 1960). Total Fe was measured in the extracts using atomic absorption spectrometry (AAS) (Shimadzu AA-6800, Kyoto, Japan). In addition, total $\mathrm{Mn}$ and $\mathrm{Al}$ were measured in the same extracts using AAS. Soil organic matter content was determined by loss-on-ignition (Nelson and Sommers, 1996) and total soil $\mathrm{N}$ by the Kjeldahl method (Bremner, 1996). Soil pH was determined in a 1:1 soil/solution ratio using deionized water and a $\mathrm{pH}$ meter (Metrohm 744, Herisau, Switzerland) with a combination glass electrode. Water extracts were collected to determine native concentrations of important anions $\left(\mathrm{NO}_{3}{ }^{-}, \mathrm{NO}_{2}{ }^{-}, \mathrm{Cl}^{-}\right.$, $\mathrm{SO}_{4}{ }^{2-}$, and $\mathrm{PO}_{4}^{-}$) and cations (total $\mathrm{Fe}$ and total $\mathrm{Mn}$ ). Results of chemical analyses were calculated on a dry-weight basis.

$\mathrm{X}$-ray diffraction patterns were measured using a Siemens D-500 diffractometer with $\mathrm{Cu} \mathrm{K} \alpha$ radiation and a current of 30 milliamps (Bruker AXS, Madison, WI). Intensities were recorded with a $0.05^{\circ}$ step width and 1 -s counting time per step. The powder method was used for the silt fraction and the scan range was 2 to $90^{\circ} 2 \theta$. Oriented slides were prepared using clay subsamples saturated with $\mathrm{Mg}, \mathrm{K}$, and $\mathrm{Mg}$ glycerol solvated and scanned from 2 to $30^{\circ} 2 \theta$. Cation exchange capacity was determined for the $<2-\mu \mathrm{m}$ fraction using $\mathrm{Ca}-\mathrm{Mg}$ exchange.

A subsample of the $<2-\mu \mathrm{m}$ size fraction was examined using a Hitachi S-3200 scanning electron microscope equipped with a Noran Voyager energy dispersive x-ray spectrometer (Thermo Electron Corp., Waltham, MA) to better understand the chemical nature of $\mathrm{Fe}$ in the untreated clay fraction. The sample was prepared by sprinkling it on a C-covered sample stub attached to an $\mathrm{Al}$ holder that was sputter coated with $\mathrm{Au}-\mathrm{Pd}$.

\section{Anoxic Stirred-Batch Experiments}

Anoxic conditions were chosen to eliminate $\mathrm{O}_{2}$ as a potential electron acceptor of $\mathrm{Fe}(\mathrm{II})$. All sample handling was conducted under an Ar atmosphere in a glove box to ensure anoxic conditions. Deionized water was purged for $3 \mathrm{~h}$ with high-purity Ar gas and transferred to the glove box for use in stirred-batch 
experiments and preparation of solutions. Dissolved $\mathrm{O}_{2}$ concentrations of Ar-deoxygenated water were measured periodically with a Clark-type polarographic electrode (Warner Instruments, Hamden, CT). Values ranged from 0.5 to $2 \mu \mathrm{mol} \mathrm{L}{ }^{-1}$, verifying anoxic conditions.

The $<2-\mathrm{mm}$ size fraction of the Sadler soil was used in five treatments (Table 1) of anoxic stirred-batch experiments. Experiments were prepared by adding $2 \mathrm{~g}$ of Sadler soil to a borosilicate glass serum bottle, after which $20 \mathrm{~mL}$ of Ar-deoxygenated water was added. The bottles were sealed with a rubber septum and allowed to prehydrate overnight. The reduction of $\mathrm{NO}_{3}{ }^{-}$was initiated by adding an aliquot of $1 \mathrm{MNO}_{3}{ }^{-}$stock solution (prepared from a $\mathrm{NaNO}_{3}$ salt) to a stirred soil suspension to achieve initial $\mathrm{NO}_{3}{ }^{-}$concentrations of 1000 and $50 \mu \mathrm{mol} \mathrm{L}{ }^{-1}$, corresponding to approximately 12 and $0.5 \mathrm{mmol} \mathrm{kg} \mathrm{m}^{-1}$ air-dried soil. These treatments are referred to as high $N$ and low $N$ (Table 1). Stirring was achieved using isotemp magnetic stir plates (Fisher Scientific, Hampton, NH) set to $350 \mathrm{rpm}$ and experiments were conducted at room temperature $\left(23-25^{\circ} \mathrm{C}\right)$. Suspension aliquots (1-2 mL) were withdrawn at $0.02,1,2,4,6,8$, and $24 \mathrm{~h}$ for high$\mathrm{N}$ treatments and $0.02,0.08,0.17,0.25,0.5,1,1.5,2$, and $4 \mathrm{~h}$ for the low-N treatment. Sampling times for soil oxalate Fe(II) extractions were $0.02,1,4$, and $24 \mathrm{~h}$. Redox potential and $\mathrm{pH}$ were measured in soil slurries at 0,4 , and $24 \mathrm{~h}$ of reaction time.

We also studied the effect of adding $\mathrm{WO}_{4}{ }^{2-}$ to inhibit production of active nitrate reductase (Scott et al., 1979; Smith, 1983). The purpose of inhibiting nitrate reductase was twofold: to evaluate contributions of the nitrate reductase competitive pathway and of the autotrophic pathway to inhibiting Fe(II) production. This treatment (high $\mathrm{N}-\mathrm{W}$ ) was identical to high $\mathrm{N}$ except Ar-deoxygenated water was added to the soil with 10 $\mathrm{m} M \mathrm{Na}_{2} \mathrm{WO}_{4}$ (Table 1) and allowed to prehydrate overnight. Sampling times for high N-W were modified slightly because of slower $\mathrm{NO}_{3}{ }^{-}$reduction kinetics (see results below). To account for abiotic reactions, anoxic soil slurries were sterilized by autoclaving at $120^{\circ} \mathrm{C}(\sim 138 \mathrm{kPa})$ for $30 \mathrm{~min}$ as described elsewhere (Tratnyek and Wolfe, 1993). Bottles were returned to the anoxic chamber and allowed to cool to room temperature before addition of $1000 \mu \mathrm{mol} \mathrm{L}{ }^{-1} \mathrm{NO}_{3}{ }^{-}$. The sterile treatment (high $\mathrm{N}$-sterile) was otherwise treated identically to high $\mathrm{N}$.

Control experiments (no added $\mathrm{NO}_{3}{ }^{-}$, Table 1 ) were reacted simultaneously with each series of treatments (high $\mathrm{N}$, low $\mathrm{N}$, high $\mathrm{N}-\mathrm{W}$, high $\mathrm{N}$-sterile) to examine treatment-induced changes in $\mathrm{Fe}(\mathrm{II})$ and other soil properties $\left(\mathrm{pH}\right.$ and $\left.\mathrm{E}_{\mathrm{H}}\right)$. When making comparisons among treatment controls, the controls were referred to as high-N control and high-N-W control, for example.

Additional experiments were conducted under anoxic conditions to include a range of initial $\mathrm{NO}_{3}{ }^{-}$concentrations $(50$, 100,500 , and $\left.1000 \mu \mathrm{mol} \mathrm{L}^{-1}\right)$. Initial rates of $\mathrm{NO}_{3}{ }^{-}$removal

Table 1. Description of the treatments imposed for anoxic stirred-batch experiments.

\begin{tabular}{lll}
\multicolumn{1}{c}{ Objective } & \multicolumn{1}{c}{$\begin{array}{c}\text { Treatment } \\
\text { designation }\end{array}$} & \multicolumn{1}{c}{ Description } \\
\hline Follow $\mathrm{NO}_{3}{ }^{-}$reduction and Fe(II) consumption & high $\mathrm{N}$ & $1 \mathrm{mM} \mathrm{NO}_{3}{ }^{-}+$anoxic soil \\
Effect of lowering $\mathrm{NO}_{3}{ }^{-}$conc. & $\operatorname{low~N}$ & $0.005 \mathrm{mM} \mathrm{NO}_{3}{ }^{-}+$anoxic soil \\
Inhibit $\mathrm{NO}_{3}{ }^{-}$reductase & high $\mathrm{N}-\mathrm{W}$ & $1 \mathrm{mM} \mathrm{NO}_{3}{ }^{-}+$anoxic soil $+10 \mathrm{mM} \mathrm{WO}_{4}{ }^{2-}$ \\
Account for abiotic reactions & high $\mathrm{N}$-sterile & $1 \mathrm{mM} \mathrm{NO}_{3}{ }^{-}+$autoclaved anoxic soil \\
Measure $\mathrm{Fe}(\mathrm{II})$ in absence of $\mathrm{NO}_{3}{ }^{-}$ & control & no added $\mathrm{NO}_{3}{ }^{-}$ \\
\hline
\end{tabular}

were followed and fit to the Michaelis-Menten expression using nonlinear regression:

$$
v=\frac{V_{\max }\left[\mathrm{NO}_{3}^{-}\right]}{K_{\mathrm{m}}+\left[\mathrm{NO}_{3}^{-}\right]}
$$

where $v$ is the initial rate of $\mathrm{NO}_{3}{ }^{-}$removal $\left(\mathrm{mmol} \mathrm{L}^{-1} \mathrm{~min}^{-1}\right)$, $V_{\max }$ is the estimated maximum rate $\left(\mathrm{mmol} \mathrm{L}^{-1} \mathrm{~min}^{-1}\right)$, and $K_{\mathrm{m}}$ is the affinity constant for the substrate $\left(\mu \mathrm{mol} \mathrm{L}{ }^{-1}\right)$. The $K_{\mathrm{m}}$ value corresponds to the $\mathrm{NO}_{3}{ }^{-}$concentration at which the rate reaches half the maximum rate. Thus, a smaller $K_{\mathrm{m}}$ represents a stronger affinity between enzyme and substrate.

\section{Chemical Analysis of Stirred-Batch Samples}

Slurry aliquots were passed through a $0.2-\mu \mathrm{m}$ membrane filter. Filtrates were immediately mixed with ferrozine [3-(2pyridyl)-5,6-diphenyl-1,2,4-triazine-4', 4"-disulfonic acid monosodium salt] buffered to $\mathrm{pH} 5.5$ with MES [2-( $N$-morph olino)ethanesulfonic acid monohydrate] to complex dissolved $\mathrm{Fe}(\mathrm{II})$. Absorbance spectra of the Fe(II)-ferrozine complex were recorded at $562 \mathrm{~nm}$ (Stookey, 1970) in Suprasil quartz cuvettes (Hereaus Optics, Buford, GA) with a 1-cm optical pathlength at $24^{\circ} \mathrm{C}$ on a double-beam Shimadzu UV-3101PC spectrophotometer (Kyoto, Japan) against appropriate standards. The estimated method detection limit is $0.5 \mu \mathrm{mol} \mathrm{L} \mathrm{L}^{-1}$ in a $1-\mathrm{cm}$ cell. Total Fe concentrations in ferrozine solutions were measured using AAS. The difference between total Fe and Fe(II) was used to estimate dissolved Fe(III). Total Mn concentrations in the filtrates were measured using AAS.

Nitrate and $\mathrm{NO}_{2}{ }^{-}$in filtrates were quantified by ion chromatography with conductivity detection using a Metrohm 792 Basic IC with a MetroSep A column and MetroSep RP guard disc holder and a $3.2 \mathrm{mmol} \mathrm{L}^{-1} \mathrm{Na}_{2} \mathrm{CO}_{3} / 1 \mathrm{mmol} \mathrm{L}^{-1} \mathrm{HCO}_{3}{ }^{-}$ eluent (Metrohm, Houston, TX). Typical retention times for $\mathrm{NO}_{2}{ }^{-}$and $\mathrm{NO}_{3}{ }^{-}$were 6 and 9 min. In some cases, orthophosphate and $\mathrm{SO}_{4}{ }^{2-}$ were quantified at 11.6 and $13.1 \mathrm{~min}$, respectively. The indophenol blue method was used for quantification of $\mathrm{NH}_{4}{ }^{+}$on the remaining sample filtrates uncomplexed with ferrozine (Weatherburn, 1967). The redox potential was measured with a Metrohm combination Pt electrode with an $\mathrm{Ag}-\mathrm{AgCl}$ reference electrode and corrected to the standard $\mathrm{H}$ electrode by adding $199 \mathrm{mV}$ (Patrick et al., 1996). Total alkalinity in water extracts of control bottles was determined by titration with standardized $0.05 \mathrm{MHCl}$.

The acid ammonium oxalate extraction $(0.2 \mathrm{M}$ at $\mathrm{pH} 3)$ described by Phillips and Lovley (1987) was used to extract solid-phase $\mathrm{Fe}(\mathrm{II})$. The method targets reduced Fe(II) phases such as magnetite $\left[\mathrm{Fe}_{3} \mathrm{O}_{4(\mathrm{~s})}\right]$ and siderite $\left[\mathrm{FeCO}_{3(\mathrm{~s})}\right]$ and poorly crystalline $\mathrm{Fe}(\mathrm{III})$ minerals (Van Bodegom et al., 2003). An oxalate extraction would also remove adsorbed $\mathrm{Fe}(\mathrm{II})$. Soil slurry aliquots, between 0.1 and $0.5 \mathrm{~mL}$, were pipetted into $20-\mathrm{mL}$ glass serum bottles and combined with oxalate. Bottles were sealed with butyl rubber stoppers and $\mathrm{Al}$ crimp caps and shaken for $24 \mathrm{~h}$ in the dark. Bottles 
were decapped and suspensions were filtered through $0.2-\mu \mathrm{m}$ membrane filters. An aliquot of filtrate was combined with ferrozine and pH 5.5 MES buffer and Fe(II) was quantified as described above. Because the percentage change in Fe(III) during the experiments was small compared with the total Fe(III) already present in the soil (see below), it was decided to express the values as Fe(II) to avoid uncertainty in the data. The inhibition percentage of Fe(II) production was calculated as described in DiChristina (1992):

$$
\text { inhibition percentage }=\left\{1-\left[\frac{\mathrm{Fe}(\mathrm{II})_{\text {treatment }}}{\mathrm{Fe}(\mathrm{II})_{\text {control }}}\right]\right\} 100
$$

The sum of dissolved Fe(II) and oxalate-extractable Fe(II) concentrations for each treatment and its control represented the values for $\mathrm{Fe}(\mathrm{II})_{\text {treatment }}$ and $\mathrm{Fe}(\mathrm{II})_{\text {control}}$, respectively.

Geochemical modeling was used to assess possible Fe(II) solid phases such as siderite and magnetite that may form by computing saturation indices [SI $=\log$ (ion activity product/solubility product constant)] with MINEQL+ (Schecher, 1998). Precipitation is favored when SI > 0, indicating that solutions are supersaturated with respect to the mineral. SI values $<0$ indicate that solutions are undersaturated with respect to precipitation of the mineral.

\section{RESULTS}

\section{Untreated Soil Characteristics}

The Sadler soil contains 22\% sand, $67 \%$ silt, and $11 \%$ clay. The soil had an initial $\mathrm{pH}$ of 7.1 and total organic $\mathrm{C}$ and $\mathrm{N}$ values of 13 and $1.2 \mathrm{~g} \mathrm{~kg}^{-1}$. Initial $\mathrm{NO}_{3}{ }^{-}$and $\mathrm{SO}_{4}{ }^{2-}$ concentrations in water extracts were $11 \pm 4$ and $17 \pm 5 \mu M$, respectively. The whole soil, silt, and clay fractions contained oxalate-extractable Fe/Na dithionite-citrate-bicarbonate (DCB)-extractable Fe ratios of $0.33,0.32$, and 0.47 (Table 2). This suggests the presence of crystalline Fe(III) oxides (Schwertmann and Cornell, 1991); however, these extractants will also chemically reduce structural Fe(III) from phyllosilicate minerals (Roth et al., 1969; Komadel et al., 1990). Quartz was the predominant mineral identified in the silt fraction, with a trace of feldspar, based on x-ray diffraction (XRD) analysis. The clay fraction, which accounted for only $11 \%$ of the dry weight of the soil, contributed 36 and $56 \%$ of the total oxalate- and DCB-extractable Fe (Table 2). Thus, the chemistry and mineralogy of this fraction was studied further.

Mineralogy of the clay $(<2-\mu \mathrm{m})$ fraction was mixed and dominated by hydroxy-interlayered vermiculite (HIV) and kaolinite. The HIV was identified in the Mg-saturated sample by the 1.3-nm XRD peak, which failed to expand on glycerol treatment and collapsed to $1.0 \mathrm{~nm}$ in the $\mathrm{K}$-saturated sample at $550^{\circ} \mathrm{C}$ (Fig. 1a). The presence of kaolinite was confirmed by the disappearance of the $0.7-\mathrm{nm}$ peak at $550^{\circ} \mathrm{C}$ in the K-saturated sample. Quartz was present based on diagnostic $\mathrm{d}$-spacings at 0.33 and $0.42 \mathrm{~nm}$ (not shown). The measured cation exchange capacity of the clay fraction was $39 \pm 11 \mathrm{cmol}_{\mathrm{c}} \mathrm{kg}^{-1}$, consistent with low-charge kaolinite and steric block- age of interlayer charge sites by the hydroxyl interlayer in HIV (Barnhisel and Bertsch, 1989). Representative scanning electron microscope (SEM) micrographs of the clay size fraction showed that Fe was associated with phyllosilicate minerals. Particles with platy morphology and diameters that were 2 to $3 \mu \mathrm{m}$ were common and typified by relative $\mathrm{Si} / \mathrm{Al}$ ratios of 1.75 (Fig. 1b). These findings, in combination with the considerable oxalate-extractable $\mathrm{Al}$ (Table 2), are consistent with HIV containing $\mathrm{Al}$ interlayers. A peak at $6.4 \mathrm{keV}$ in the energy dispersive spectra was identified as the $\mathrm{k} \alpha$ feature of Fe. Iron could be present as a structural cation in the octahedral sheet of HIV, in agreement with published average structural chemical formulas for HIV (Barnhisel and Bertsch, 1989). Discrete Fe(III) (oxy)hydroxides were not detected by XRD or SEM in the clay fraction. This suggests that they are either absent or below detection limits.

\section{Anoxic Control Experiments}

The reduction of $\mathrm{Fe}(\mathrm{III})$ in high-N control soil slurries was evident based on $\mathrm{Fe}(\mathrm{II})$ accumulation in the dissolved and oxalate-extractable pools (Fig. $2 \mathrm{a}$ and $2 \mathrm{~b}$ ). The concentration of oxalate-extractable $\mathrm{Fe}(\mathrm{II})$ produced was only a small fraction of the total oxalate-extractable $\mathrm{Fe}\left(\mathrm{Fe}_{\mathrm{ox}}\right.$ in Table 2$)$, indicating that a majority of the Fe still remained as Fe(III). The measured redox potential $\left(\mathrm{E}_{\mathrm{H}}\right)$ in control bottles for both high $\mathrm{N}$ and high $\mathrm{N}-\mathrm{W}$ verified that conditions were $\mathrm{Fe}(\mathrm{III})$ reducing (Table 3 ). The rise in soil $\mathrm{pH}$ is consistent with bioreduction of soil Fe(III) (Table 3) due to proton consumption (Munch and Ottow,1980).

In general, $\mathrm{Fe}(\mathrm{II})$ production in the oxalate-extractable fraction was at least 10 times greater than the dissolved $\mathrm{Fe}(\mathrm{II})$ fraction (Fig. 2a,b). This suggests that as Fe(III) reduction proceeds, the released Fe(II) reprecipitates as solid Fe(II) minerals (Fredrickson et al., 1998; Zachara et al., 2002) or resorbs to the soil (Kukkadapu et al., 2001). Regarding the former scenario, thermodynamic modeling indicated that solutions were supersaturated with respect to siderite precipitation based on SI values $>1$ in all treatments and controls (Table 3). Siderite is a common secondary product of crystalline and poorly crystalline Fe(III) (hydr)oxide reduction (Fredrickson et al., 1998; Lovley, 2000; Zachara et al., 2002). In our calculations, it was assumed that the carbonate required for $\mathrm{FeCO}_{3(\mathrm{~s})}$ precipitation originated from the alkalinity generated (as measured by titration in control bottles) during microbial decomposition of organic C coupled to dissimilatory $\mathrm{Fe}(\mathrm{III})$ reduction under anoxic conditions (Suess, 1979). As pointed out by Zachara
Table 2. Chemical characterization of the Sadler silt loam soil and size fractionst.

\begin{tabular}{lcccccc}
\multicolumn{1}{c}{ Fraction } & $\mathbf{F e}_{\mathbf{D C B}}$ & $\mathbf{M n}_{\mathbf{D C B}}$ & $\mathbf{A l}_{\mathbf{D C B}}$ & $\mathbf{F e}_{\mathbf{o x}}$ & $\mathbf{M n}_{\mathbf{o x}}$ & $\mathbf{A l}_{\mathbf{o x}}$ \\
\hline & \multicolumn{7}{c}{$\mathrm{mmol} \mathrm{kg}^{-1}$} \\
Whole soil & $157(6.4) \neq$ & $15.0(2)$ & $52.3(1)$ & $53.2(4)$ & $12.2(1.2)$ & $\mathrm{ND \S}$ \\
Sand & $20.9(12.6)$ & $2.95(2.4)$ & $8.2(4.4)$ & $9.9(2.4)$ & $1.28(0.4)$ & $6.4(0.7)$ \\
Silt & $25.7(2.3)$ & $1.81(0.1)$ & $21.6(3.6)$ & $38.2(32.2)$ & $2.35(0.2)$ & $11.4(9.4)$ \\
Clay & $58.7(0.1)$ & $3.43(0.2)$ & $21.7(1.2)$ & $26.5(5.6)$ & $10.2(3.3)$ & $74.0(6.7)$ \\
\hline
\end{tabular}

$+\mathrm{Fe}_{\mathrm{DCB}}, \mathrm{Al}_{\mathrm{DCB}}$, and $\mathrm{Mn}_{\mathrm{DCB}}$ (dithionite-citrate-bicarbonate-extractable $\mathrm{Fe}, \mathrm{Al}$, and $\mathrm{Mn}$, respectively) were extracted according to Mehra and Jackson (1960); $\mathrm{Al}_{\mathrm{Ox}^{\prime}}, \mathrm{Fe}_{\mathrm{Ox}^{\prime}}$ and $\mathrm{Mn}_{\mathrm{Ox}}$ (oxalate-extractable Fe, Al, and Mn, respectively) extracted according to Phillips and Lovley (1987).

¥ Values in parentheses represent one standard deviation from the mean. 
et al. (2002), siderite precipitation can occur biologically and abiologically, with the latter possibly occurring at a faster rate.

A factor that could potentially inhibit $\mathrm{Fe}$ (II) production is the presence of $\mathrm{Mn}$ (III,IV) oxide minerals (Table 2). Manganese(III,IV) oxide minerals that persist under the reducing conditions encountered here in a state of redox disequilibrium could react with $\mathrm{Fe}(\mathrm{II})$, producing $\mathrm{Fe}(\mathrm{III})$ (Hyacinthe et al., 2001). If this occurred, then an increase in dissolved $\mathrm{Mn}$ and a decrease in dissolved Fe(II) would be expected. Total dissolved $\mathrm{Mn}$ in control bottles remained constant (data not shown) and dissolved $\mathrm{Fe}(\mathrm{II})$ increased (Fig. 2a), ruling out this possibility.

\section{Impact of Nitrate on Iron(II) Production}

Results of the high-N experiments are shown in Fig. 2. The addition of $1000 \mu \mathrm{mol} \mathrm{L}{ }^{-1} \mathrm{NO}_{3}^{-}\left(\sim 12.5 \mathrm{mmol} \mathrm{kg}^{-1}\right)$ inhibited $\mathrm{Fe}(\mathrm{II})$ production in both the oxalate-extractable and dissolved fractions (Fig. 2a and 2b). The inhibitory effects increased

A

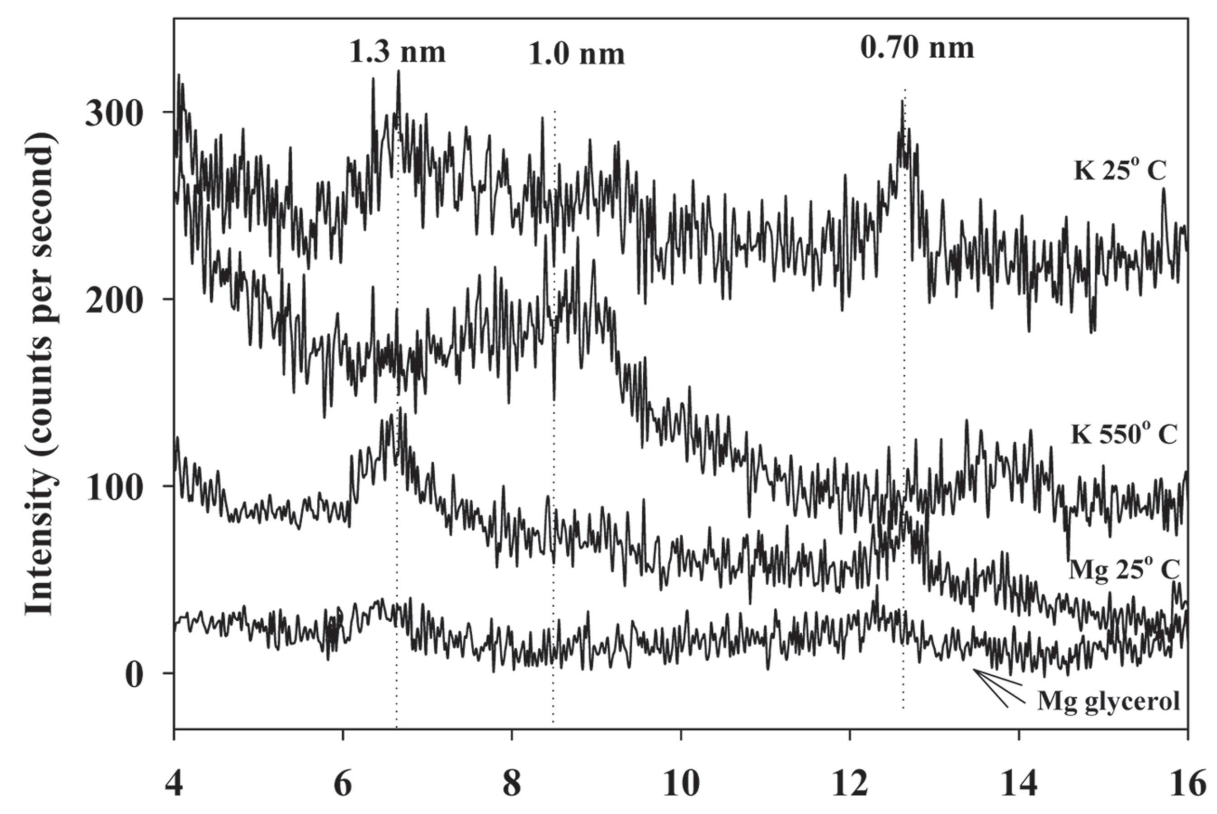

\section{Degrees $2 \theta$}

B

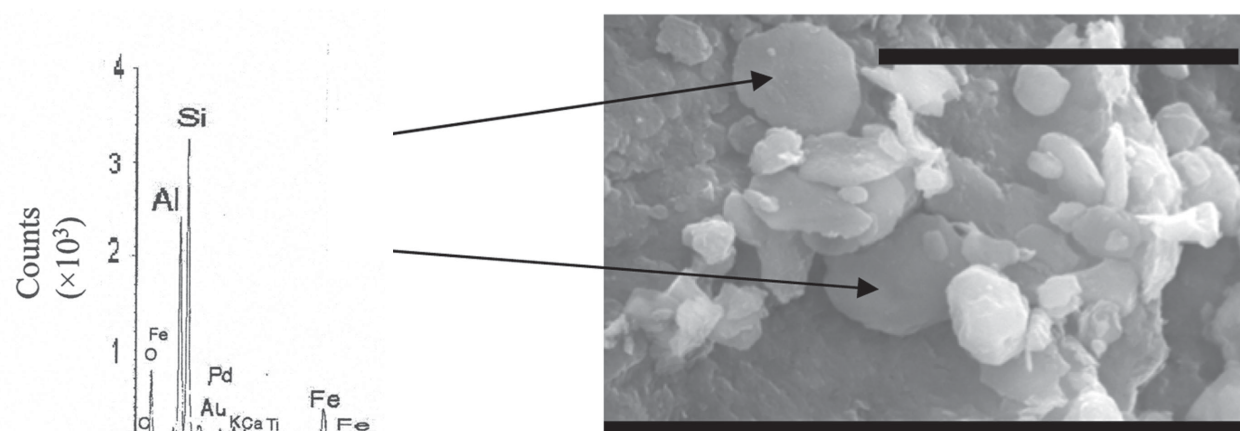

Fig. 1. (A) X-ray diffraction patterns of the clay fraction after $\mathrm{Mg}$ saturation at $25^{\circ} \mathrm{C}, \mathrm{Mg}$ glycerol solvation at $25^{\circ} \mathrm{C}, \mathrm{K}$ saturation at $25^{\circ} \mathrm{C}$, and $\mathrm{K}$ saturation at $550^{\circ} \mathrm{C}$; (B) representative scanning electron micrograph of the clay fraction. The energy dispersive $\mathrm{x}$-ray spectrum shown corresponds to the platy particle indicated by the arrows. The Au and Pd were a result of the coating process. Scale bar equals $5 \mu \mathrm{m}$ and no peaks were detected beyond $10 \mathrm{keV}$. sharply with time, from $10 \%$ after $1 \mathrm{~h}$ to $85 \%$ after $24 \mathrm{~h}$ (Table 4). Dissolved $\mathrm{Fe}(\mathrm{III})$ production was accelerated in the high-N treatments, generally greater than the control with an apparent plateau reached after $\sim 6 \mathrm{~h}$ (Fig. 2c). In contrast, there was a small but noticeable decrease in dissolved Fe(III) in the control bottles, corresponding to conditions that became more reducing during the experiments (Table 3).

The inhibition of $\mathrm{Fe}(\mathrm{II})$ production coincided with reduction of $\mathrm{NO}_{3}{ }^{-}$, which was reduced at a rate of $0.68( \pm 0.06)$ mmol kg-1 $\mathrm{h}^{-1}\left(R^{2}=0.99, p<0.001\right.$; Fig. $\left.2 \mathrm{~d}\right)$. $\mathrm{No} \mathrm{NO}_{2}{ }^{-}$was detected as an intermediate and only slight increases in $\mathrm{NH}_{4}^{+}$ were observed, accounting for only $\sim 5 \%$ of the reduced $\mathrm{NO}_{3}-$ (data not shown).

The predominantly biological nature of $\mathrm{NO}_{3}{ }^{-}$reduction was shown by the sensitivity toward autoclaving (Fig. 2d, high $\mathrm{N}$-sterile). Additional evidence in support of a biological reduction of $\mathrm{NO}_{3}^{-}$was found in the saturation behavior shown by $\mathrm{NO}_{3}^{-}$. Nitrate reduction was described well by Michaelis-Menten kinetics $\left(r^{2}=\right.$ 0.99; Fig. 3). The affinity constant $K_{\mathrm{m}}$ value derived from the fit of Eq. [1] to the data in Fig. 3 was $70 \mu \mathrm{mol} \mathrm{L}{ }^{-1}$ $\mathrm{NO}_{3}{ }^{-}$and $V_{\max }$ was $1.2 \mu \mathrm{mol} \mathrm{L}-1$ $\mathrm{NO}_{3}{ }^{-} \min ^{-1}$.

Results where the initial $\mathrm{NO}_{3}^{-}$ concentration was lowered (low N) are shown in Fig. 4. There was an immediate inhibition in $\mathrm{Fe}(\mathrm{II})$ production of $66 \%$ after $1 \mathrm{~h}$ where most of the $\mathrm{NO}_{3}{ }^{-}$was reduced (Fig. $4 \mathrm{a}$ and $4 \mathrm{~b}$, Table 4). The rate of $\mathrm{NO}_{3}{ }^{-}$reduction was $0.3( \pm 0.02)$ mmol kg${ }^{-1} \mathrm{~h}^{-1}$. After $\mathrm{NO}_{3}{ }^{-}$depletion, $\mathrm{Fe}$ (III) reduction resumed in the low-N slurries. This was shown by the drop in $\mathrm{Fe}(\mathrm{II})$ inhibition at 4 and $24 \mathrm{~h}$ (Table 4).

\section{Effect of Tungstate on Nitrate Reduction and Iron(II) Production}

The response of $\mathrm{NO}_{3}{ }^{-}$reduction and $\mathrm{Fe}(\mathrm{II})$ production to added $\mathrm{WO}_{4}^{2-}$ in soil slurries is shown in Fig. 5. It appears that $\mathrm{WO}_{4}{ }^{2-}$ elicited inhibitory effects on $\mathrm{Fe}(\mathrm{III})$ reduction based on three- to fourfold less oxalate-extractable $\mathrm{Fe}(\mathrm{II})$ in high-N-W control slurries than their high-N control counterparts at the outset of the reactions (compare Fig. 5b and Fig. 2b). As a result, introduction of $\mathrm{NO}_{3}^{-}$in soil slurries treated with $\mathrm{WO}_{4}^{2-}$ (high $\mathrm{N}-\mathrm{W}$ ) resulted in a different inhibition pattern than the high-N treatment (Fig. 5a and $5 b)$. The greatest inhibition in $\mathrm{Fe}(\mathrm{II})$ production was observed during the first $4 \mathrm{~h}$ of reaction, followed by only 
a slight inhibition at $24 \mathrm{~h}$ (Table 4). It is possible that this early inhibition of $\mathrm{Fe}(\mathrm{II})$ production arose from cells taking time to build new electron transport chains to use $\mathrm{Fe}(\mathrm{III})$ as an electron acceptor now that $\mathrm{NO}_{3}{ }^{-}$was blocked. No clear trend was evident in dissolved $\mathrm{Fe}(\mathrm{III})$ in response to $\mathrm{NO}_{3}{ }^{-}$addition (Fig. 5c).

The rate of $\mathrm{NO}_{3}{ }^{-}$reduction in high N-W (Fig. $5 \mathrm{~d}$ ) was 0.14 $( \pm 0.01) \mathrm{mmol} \mathrm{kg}^{-1} \mathrm{~h}^{-1}\left(R^{2}=\right.$ $0.99, p<0.001)$. This rate was approximately fivefold less than the high- $\mathrm{N}$ experiments and twofold less than the low- $\mathrm{N}$ treatment.

\section{DISCUSSION \\ Inhibition of Soil Iron(II) \\ Production by Nitrate Reductase}

As already mentioned, several hypothetical pathways have been proposed to explain the mechanism of the suppression of $\mathrm{Fe}(\mathrm{II})$ production following addition of $\mathrm{NO}_{3}{ }^{-}$. Inhibition of $\mathrm{Fe}(\mathrm{II})$ production cannot be explained by an increase in $\mathrm{E}_{\mathrm{H}}$ in high-N and high-N-W experiments (Table 4). Although the variability was high, $\mathrm{E}_{\mathrm{H}}$ values never rose above $-100 \mathrm{mV}$ during the course of the reaction for high-N and high-N-W soil slurries (Table 3). All values were well within the Fe(III)-reducing zone (Patrick et al., 1996) and did not increase to positive potentials $(200-400 \mathrm{mV}$ ) as suggested elsewhere (Ponnamperuma and Castro, 1964; Ponnamperuma, 1972) to explain the inhibition of $\mathrm{Fe}(\mathrm{II})$ production by $\mathrm{NO}_{3}{ }^{-}$. Similarly, Klüber and Conrad (1998) reported no change in redox potential due to addition of $1000 \mu \mathrm{mol} \mathrm{L}^{-1} \mathrm{NO}_{3}{ }^{-}$to anoxic rice (Oryza sativa L.) paddy soil slurries. The $\mathrm{pH}$ values tended to increase with reaction time in high $\mathrm{N}$, high $\mathrm{N}-\mathrm{W}$, and their duplicate or triplicate runs.
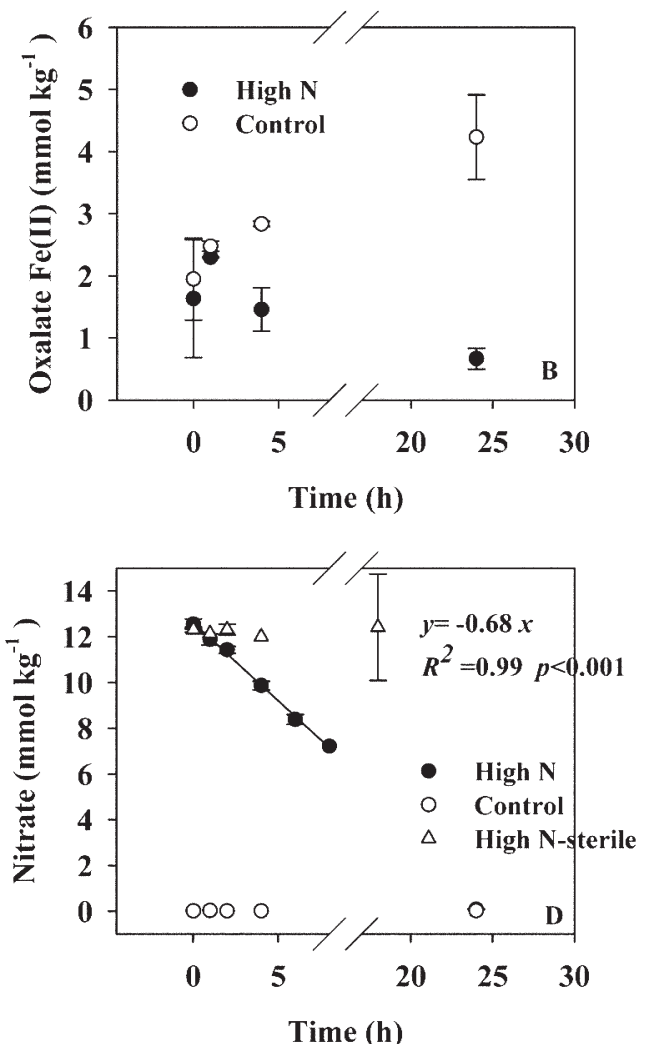

Fig. 2. Time course of (A) solution Fe(II), (B) oxalate-extractable Fe(II), (C) solution Fe(III), and (D) solution $\mathrm{NO}_{3}{ }^{-}$for the high- $\mathrm{N}$ treatment and high- $\mathrm{N}$ control soil slurries. The solution $\mathrm{NO}_{3}{ }^{-}$values for high-N-sterile are plotted in (D). Error bars represent the standard deviation from the mean for

controls (Table 3). This suggests that changes in $\mathrm{pH}$ or $\mathrm{E}_{\mathrm{H}}$ were not responsible for the inhibitory effects in $\mathrm{Fe}(\mathrm{II})$ production.

According to the nitrate reductase competitive model (second hypothesis), $\mathrm{NO}_{3}{ }^{-}$would be preferentially used as an electron acceptor. Once all the $\mathrm{NO}_{3}{ }^{-}$was reduced, then $\mathrm{Fe}(\mathrm{III})$ would be used as an electron acceptor and $\mathrm{Fe}(\mathrm{II})$ production would resume (Munch and Ottow, 1980; Sorensen, 1982). In the high-N experiments, the inhibition in $\mathrm{Fe}(\mathrm{II})$ production increased $>70 \%$ from 1 to $24 \mathrm{~h}$ as $\mathrm{NO}_{3}{ }^{-}$was being reduced (Fig. 2a, 2b, and 2d, Table 4). Iron(II) production resumed after $48 \mathrm{~h}$ subsequent to complete $\mathrm{NO}_{3}{ }^{-}$depletion (data not shown). At low initial $\mathrm{NO}_{3}{ }^{-}$concentrations (low $\mathrm{N}$ ), the maximum in $\mathrm{Fe}(\mathrm{II})$ inhibition occurred

Table 3. The $\mathrm{pH}$, reduction potential $\left(\mathrm{E}_{\mathrm{H}}\right)$, and calculated saturation indices (SI)+ for predicted Fe(II) mineral solids in high- $\mathrm{N}$ and high-N-W treatments and their controls.

\begin{tabular}{|c|c|c|c|c|c|c|c|c|c|c|}
\hline \multirow{3}{*}{ Treatment } & \multirow{2}{*}{\multicolumn{3}{|c|}{$\mathrm{pH}$}} & \multirow{2}{*}{\multicolumn{3}{|c|}{$\mathrm{E}_{\mathrm{H}}$}} & \multicolumn{4}{|c|}{ SI‡ } \\
\hline & & & & & & & \multicolumn{2}{|c|}{ Siderite } & \multicolumn{2}{|c|}{ Magnetite } \\
\hline & $\mathbf{O} \mathbf{h}$ & $4 \mathrm{~h}$ & $24 \mathrm{~h}$ & $\mathbf{0 ~ h}$ & $4 \mathrm{~h}$ & $24 \mathrm{~h}$ & $\mathbf{O} \mathbf{h}$ & $24 \mathrm{~h}$ & $\mathbf{O} \mathbf{h}$ & $24 \mathrm{~h}$ \\
\hline & \multicolumn{10}{|c|}{$\longrightarrow \mathrm{mV} \longrightarrow$} \\
\hline High N & $7.8(0.1) \S$ & $7.5(0.3)$ & $8.2(0.1)$ & $-113(25)$ & $-154(5)$ & $-151(50)$ & 1.8 & 2.5 & -59 & -66 \\
\hline High $\mathrm{N}$ control & $7.8(0.1)$ & $7.6(0.1)$ & $7.9(0.1)$ & $-129(6)$ & $-206(7)$ & $-162(37)$ & 1.7 & 1.9 & -59 & -61 \\
\hline High N-W & $7.6(0.2)$ & $7.7(0.03)$ & $7.9(0.1)$ & $-124(15)$ & $-126(11)$ & $-145(15)$ & 2.1 & 2.7 & -58 & -60 \\
\hline High N-W control & $7.7(0.2)$ & ND & $8.1(0.1)$ & $-160(36)$ & ND & $-145(39)$ & 1.9 & 2.6 & -59 & -66 \\
\hline
\end{tabular}

+ Determined using MINEQL+ (Schecher, 1998). Input data included alkalinity, dissolved Fe(II), dissolved Fe(III), $\mathrm{pH}$, and $\mathrm{E}_{\mathrm{H}}$.

₹ Log ion activity product/solubility product constant.

$\S$ Values in parentheses represent one standard deviation from the mean.

I $\mathrm{ND}=$ not determined. 
Table 4. Inhibition percentage in Fe(II) production and contribution of Fe(II) oxidation to $\mathrm{NO}_{3}{ }^{-}$reduction in high- $\mathrm{N}$, high-N-W, and low- $\mathrm{N}$ treatments.

\begin{tabular}{|c|c|c|c|c|c|c|}
\hline \multirow{2}{*}{ Treatment } & \multicolumn{3}{|c|}{ Inhibition of $\mathrm{Fe}(\mathrm{II})$ production } & \multicolumn{3}{|c|}{$\mathrm{Fe}(\mathrm{II})$ oxidation by $\mathrm{NO}_{3}{ }^{-}+$} \\
\hline & $1 \mathrm{~h}$ & $4 \mathrm{~h}$ & $24 \mathrm{~h}$ & $1 \mathrm{~h}$ & $4 \mathrm{~h}$ & $24 \mathrm{~h}$ \\
\hline High $N$ & $10(0.1) \ddagger$ & $62(2)$ & $85(3)$ & $8(0.1)$ & 10(3) & $6(1)$ \\
\hline Low $\mathrm{N}$ & $66(2)$ & $53(2)$ & $0 \S$ & $87(11)$ & $51(7)$ & 0 \\
\hline High N-W & $56(17)$ & $72(10)$ & $5(4)$ & 0 & $16(6)$ & 0 \\
\hline
\end{tabular}

† Determined assuming $\mathrm{NO}_{3}{ }^{-}$was reduced to $\mathrm{N}_{2}$, and by subtracting measured Fe(II) (oxalate-extractable + dissolved) for each treatment from the control.

₹ Values in parentheses represent one standard deviation from the mean.

$\S$ Values of 0 represent points where Fe(II) production has resumed or where negligible $\mathrm{NO}_{3}{ }^{-}$has been reduced.

earlier than in the high-N treatment (Fig. 4a and 4b, Table 4). The production of $\mathrm{Fe}(\mathrm{II})$ clearly resumed after complete $\mathrm{NO}_{3}{ }^{-}$reduction in low-N treatments (Fig. $4 \mathrm{a}$ and $4 \mathrm{~b}$ ). These results agree with Sorensen (1982), who found that $\mathrm{Fe}(\mathrm{II})$ production commenced only after complete reduction of $200 \mu \mathrm{mol} \mathrm{L}^{-1} \mathrm{NO}_{3}^{-}$ in anoxic slurries. Munch and Ottow (1980) argued that $\mathrm{NO}_{3}^{-}$ will inhibit $\mathrm{Fe}(\mathrm{II})$ production in soils due to the direct action of nitrate reductase.

It was expected that addition of $\mathrm{WO}_{4}^{2-}$ would curtail $\mathrm{Fe}(\mathrm{II})$ inhibition if the nitrate reductase competitive model is the main mechanism involved. Iron(II) inhibition continued in the high$\mathrm{N}-\mathrm{W}$ experiments (Table 4); however, this trend was confounded by the unanticipated effect of $\mathrm{WO}_{4}^{2-}$ on $\mathrm{Fe}(\mathrm{III})$ reduction as much less oxalate-extractable $\mathrm{Fe}(\mathrm{II})$ was initially present in high-N-W control slurries than high-N controls (compare Fig. 5b and Fig. 2b). Nonetheless, the pronounced decrease in the $\mathrm{NO}_{3}{ }^{-}$reduction rate from $0.68 \mathrm{mmol} \mathrm{kg}^{-1} \mathrm{~h}^{-1}$ in the high-N slurries (Fig. 2d) to 0.14 mmol kg-1 $\mathrm{h}^{-1}$ in the high-N-W treatment (Fig. $5 \mathrm{~d}$ ) indicates active nitrate reductase in our system. Molybdoenzymes of $E$. coli were inactivated by similar levels of $\mathrm{WO}_{4}{ }^{2-}$, resulting in a drastic decline in nitrate reductase activity (Scott et al., 1979; Smith, 1983). In addition, negligible $\mathrm{NO}_{3}{ }^{-}$reduction in the high-N-sterile treatment (Fig. 2d) further substantiates the important role of nitrate reductase, which is inactivated by autoclaving (Sorensen, 1982).

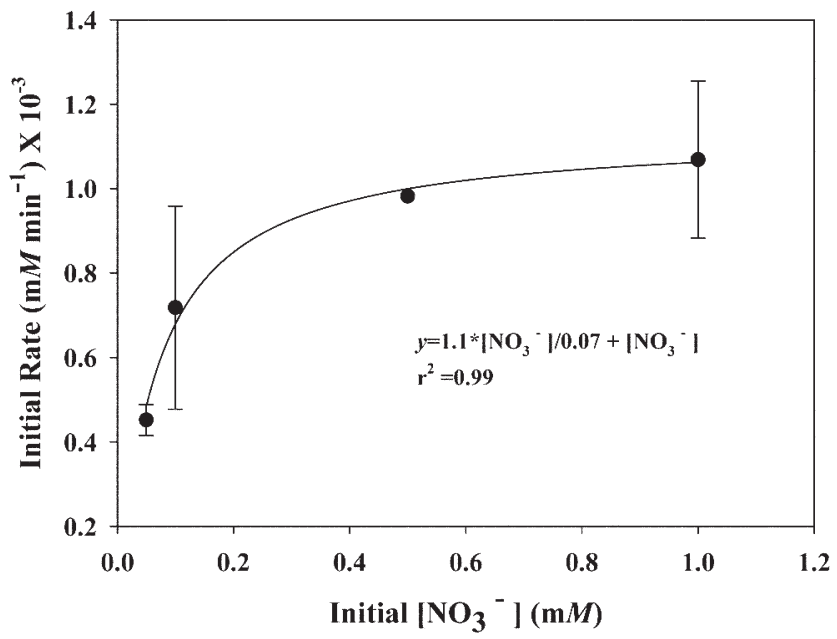

Fig. 3. Michaelis-Menten kinetic plot in anoxic soil slurries of the Sadler silt loam. The line is a nonlinear fit of the MichaelisMenten equation to the data. Error bars represent the standard deviation from the mean for duplicate or triplicate runs.
The saturation behavior displayed in $\mathrm{NO}_{3}{ }^{-}$reduction rates (Fig. 3) further supports a biological reduction of $\mathrm{NO}_{3}{ }^{-}$by the nitrate reductase enzyme. This has been ascribed to limiting soil organic $\mathrm{C}$ concentrations for heterotrophic denitrifiers (Bowman and Focht, 1974; Kohl et al., 1976). This could have been the case in our experimental systems because no $\mathrm{C}$ additions were made and the native soil organic $\mathrm{C}$ level was used $(\sim 1.3 \%)$. The apparent $K_{\mathrm{m}}$ value $\left(70 \mu \mathrm{mol} \mathrm{L} \mathrm{L}^{-1} \mathrm{NO}_{3}^{-}\right)$was lower than that reported elsewhere (Bowman and Focht, 1974; Kohl et al., 1976), suggesting greater affinity of $\mathrm{NO}_{3}{ }^{-}$in our soil. This could reflect differences in soil organic $\mathrm{C}$ availability, soil type, and experimental conditions.

It is conceivable that $\mathrm{NO}_{3}{ }^{-}$consumption was also due to $\mathrm{Fe}(\mathrm{III})$-reducing bacteria that are able to simultaneously reduce $\mathrm{NO}_{3}{ }^{-}$and $\mathrm{Fe}(\mathrm{III})$, with a preference toward $\mathrm{NO}_{3}{ }^{-}$ (DiChristina, 1992; Krause and Nealson, 1997). Several Geobacter species have been shown to reduce $\mathrm{NO}_{3}{ }^{-}$(Coates et al., 1996; Senko and Stolz, 2001) without the involvement of Mo-containing enzyme systems based on sustained nitrate reductase activity in the presence of up to $2 \times 10^{4} \mu \mathrm{mol} \mathrm{L}-1$ $\mathrm{WO}_{4}{ }^{2-}$ (Murillo et al., 1999).

\section{Inhibitory Effects due to Concomitant Iron(III) and Nitrate Reduction Coupled to Iron(II)}
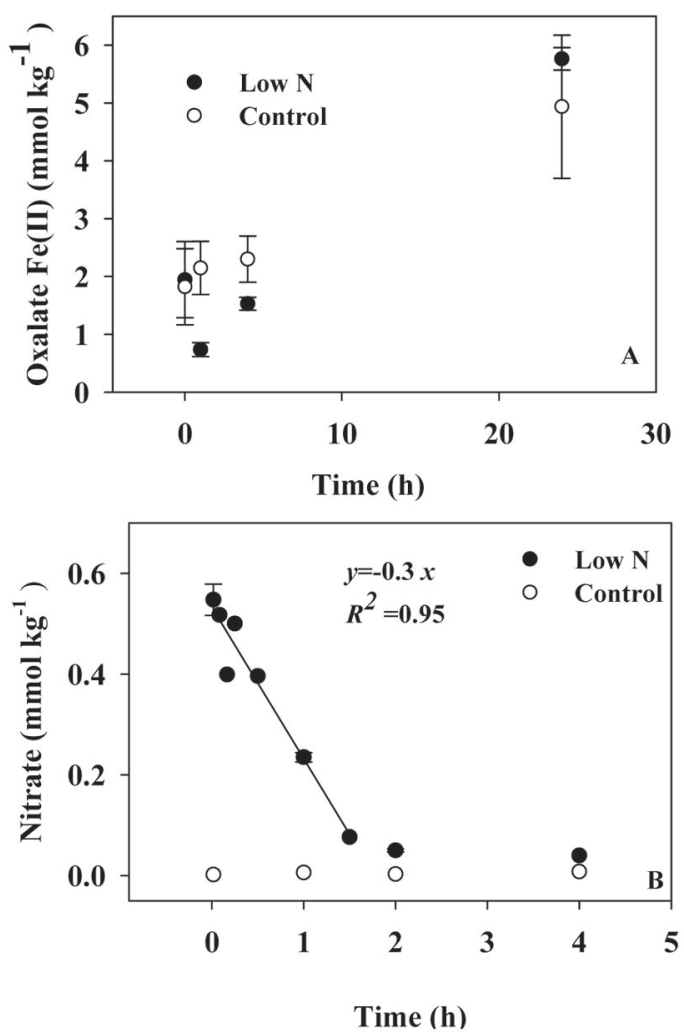

Fig. 4. Time course of (A) oxalate-extractable Fe(II), and (B) solution $\mathrm{NO}_{3}-$ for the low- $\mathrm{N}$ treatment and low- $\mathrm{N}$ control soil slurries. Error bars represent the standard deviation from the mean for duplicate or triplicate runs. 


\section{Reoxidation by Nitrite}

If $\mathrm{NO}_{3}{ }^{-}$functioned strictly as an inhibitor of $\mathrm{Fe}(\mathrm{III})$ reduction by nitrate reductase, then one would expect $\mathrm{Fe}$ (II) levels to remain constant during $\mathrm{NO}_{3}{ }^{-}$reduction as pointed out by Obuekwe et al. (1981) and observed in sediment slurries by Sorensen (1982). In our studies, however, Fe(II) levels in both dissolved and oxalate-extractable fractions were not constant during the $\mathrm{NO}_{3}{ }^{-}$reduction process, but dropped below the corresponding controls. Inhibition of $\mathrm{Fe}(\mathrm{II})$ production in high $\mathrm{N}$ and low $\mathrm{N}$ was most pronounced whenever $\mathrm{NO}_{3}{ }^{-}$was still present in solution (Fig. 2a, 2b, 2d, 4a, and 4b, Table 4). These results indicate that $\mathrm{Fe}(\mathrm{II})$ was oxidized during $\mathrm{NO}_{3}{ }^{-}$reduction and contributed to inhibiting $\mathrm{Fe}(\mathrm{II})$ production. The contributions of $\mathrm{Fe}(\mathrm{II})$ oxidation to $\mathrm{NO}_{3}{ }^{-}$ reduction were 6 to $10 \%$ in the high-N and 50 to $90 \%$ in the low$\mathrm{N}$ slurries (Table 4). Additional support for $\mathrm{Fe}$ (II) oxidation was based on the greater levels of dissolved Fe(III) produced in high-N treatments when compared with the high- $\mathrm{N}$ control (Fig. 2c). This evidence indicates that the nitrate reductase competitive model was not the only mechanism operating in the inhibition of $\mathrm{Fe}$ (II) formation by $\mathrm{NO}_{3}{ }^{-}$.

Iron(II) production in control bottles did not appear to level off during our experiments, suggesting that microbial $\mathrm{Fe}(\mathrm{III})$ reduction was proceeding at the time when $\mathrm{NO}_{3}{ }^{-}$was added (Fig. 2a, 2b, 4a, and 4b). Secondary reactions involving chemical $\mathrm{Fe}$ (II) reoxidation by $\mathrm{NO}_{2}{ }^{-}$formed during concomitant $\mathrm{Fe}(\mathrm{III})$ and $\mathrm{NO}_{3}{ }^{-}$reduction may explain the inhibitory effects in $\mathrm{Fe}(\mathrm{II})$ production (Komatsu et al., 1978; Obuekwe et al., 1981). The greatest contribution of $\mathrm{Fe}(\mathrm{II})$ oxidation to $\mathrm{NO}_{3}{ }^{-}$reduction was found in the low-N slurries (Table 4). This may be ascribed to the initial stoichiometric excess of oxalate-extractable $\mathrm{Fe}$ (II) over $\mathrm{NO}_{3}{ }^{-}$(3.5:1) in this treatment (Fig. $4 \mathrm{a}$ and $4 \mathrm{~b}$ ), whereas in high-N experiments, the ratio was $0.2: 1$ (Fig. $2 \mathrm{~b}$ and $2 \mathrm{~d}$ ). This would provide more available $\mathrm{Fe}(\mathrm{II})$ to chemically react with $\mathrm{NO}_{2}^{-}$produced as an intermediate during heterotrophic reduction of $\mathrm{NO}_{3}{ }^{-}$. Nitrite is a versatile ligand in that it can coordinate to a metal via the $\mathrm{N}$ or $\mathrm{O}$ atoms, with bonding on the $\mathrm{N}$ forming a stronger complex (Shriver et al., 1994).

One possible form of reactive $\mathrm{Fe}(\mathrm{II})$ that may chemically reduce $\mathrm{NO}_{2}{ }^{-}$in our soil systems is $\mathrm{FeCO}_{3(\mathrm{~s})}$ (Table 3). Using data compiled by Bard et al. (1985), one can compute a favorable thermodynamic driving force for oxidation of siderite by $\mathrm{NO}_{2}{ }^{-}$ to poorly crystalline Fe(III) hydroxide $\left(\Delta \mathrm{G}_{\mathrm{r}}^{\circ}=-128 \mathrm{~kJ} \mathrm{~mol}^{-1}\right)$ :
$\mathrm{NO}_{2}{ }^{-}+3 \mathrm{FeCO}_{3}(\mathrm{~s})+7 \mathrm{H}_{2} \mathrm{O} \rightarrow 3 \mathrm{Fe}(\mathrm{OH})_{3}(\mathrm{~s})+{ }^{1 / 2} \mathrm{~N}_{2}+3 \mathrm{HCO}_{3}{ }^{-}+2 \mathrm{H}^{+}$

It is not clear whether the overall reaction in Eq. [3] occurs at a rate relevant to our time series data. The importance of siderite oxidation by $\mathrm{NO}_{2}{ }^{-}$as a possible pathway in inhibiting $\mathrm{Fe}$ (II) production merits further study.

Another form of $\mathrm{Fe}(\mathrm{II})$ that may be present in our systems is adsorbed $\mathrm{Fe}(\mathrm{II})$. A wide variety of sorption sites in the Sadler soil [kaolinite, HIV, and possibly Fe(III) (hydr)oxide minerals] would be available for $\mathrm{Fe}(\mathrm{II})$ at $\mathrm{pH}$ values encountered in this study (Table 3). For example, Kukkadapu et al. (2001) reported that Fe(II) produced during biological reduction of a sediment-derived clay fraction resorbed to kaolinite. Adsorbed $\mathrm{Fe}(\mathrm{II})$ as an inner sphere complex to oxo functional groups is a strong chemical reductant, reflected by a lowered reduction potential when compared with dissolved Fe(II) (Wehrli, 1990; Luther et al., 1992). Nitrite is known to be heterogeneously reduced by adsorbed Fe(II) forms, at estimated rates of $\sim 1$ to $3.5 \mu \mathrm{mol} \mathrm{L}{ }^{-1} \mathrm{NO}_{2}^{-} \mathrm{min}^{-1}$ at $\mathrm{pH} 8$ (Van Cleemput and Baert, 1983; Sorensen and Thorling, 1991). These rates are generally faster than the rate of $\mathrm{NO}_{3}{ }^{-}$reduction in our studies $\left(0.2-1 \mu \mathrm{mol} \mathrm{L}{ }^{-1} \mathrm{NO}_{3}{ }^{-} \mathrm{min}^{-1}\right.$, Fig. $2 \mathrm{~d}$ and $\left.4 \mathrm{~d}\right)$, and may explain why $\mathrm{NO}_{2}^{-}$was not detected as an intermediate. These reactive forms of $\mathrm{Fe}$ (II) may have been rapidly oxidized to $\mathrm{Fe}(\mathrm{III})$ by $\mathrm{NO}_{2}{ }^{-}$and may explain the inhibition in $\mathrm{Fe}(\mathrm{II})$ production.

\section{Inhibitory Effects due to Autotrophic, Nitrate- Dependent Iron(II) Oxidation}

Autotrophic bacteria may also be responsible for the inhibiting effect of $\mathrm{NO}_{3}{ }^{-}$on $\mathrm{Fe}(\mathrm{II})$ production by coupling 
$\mathrm{NO}_{3}{ }^{-}$reduction to $\mathrm{Fe}(\mathrm{II})$ oxidation (Straub et al., 1996). In our experiments, the immediate oxidation of $\mathrm{Fe}$ (II) following $\mathrm{NO}_{3}{ }^{-}$addition resulted in accelerated production of dissolved $\mathrm{Fe}(\mathrm{III})$ in high-N slurries (Fig. 2a-2d). The dissolved Fe(III) is probably chelated by dissolved organic matter. Although Fe(II) oxidation could also be due to the chemical pathway mentioned above, no loss of $\mathrm{NO}_{3}{ }^{-}$was noted in the high-N-sterile slurries (Fig. 2d), nor was the production of Fe(III) (data not shown). Klüber and Conrad (1998) reported immediate production of $\mathrm{Fe}(\mathrm{III})$ coupled to $\mathrm{NO}_{3}{ }^{-}$reduction under anoxic conditions and attributed this finding to bacterial $\mathrm{Fe}(\mathrm{II})$ oxidation. Enrichment cultures of $\mathrm{NO}_{3}{ }^{-}$-dependent $\mathrm{Fe}$ (II) oxidizers produce poorly crystalline ferrihydrite $\left[\mathrm{Fe}(\mathrm{OH})_{3(\mathrm{~s})}\right]$ as the primary product of $\mathrm{Fe}(\mathrm{II})$ oxidation (Straub et al., 1996).

The $\mathrm{Fe}(\mathrm{II})$ used by $\mathrm{NO}_{3}{ }^{-}$-dependent $\mathrm{Fe}(\mathrm{II})$ oxidizers may originate from dissolved Fe(II) (Straub et al., 1996) or possibly siderite (Weber et al., 2001). In addition, structural Fe(III) in HIV (Fig. 1) that is reduced may provide the available Fe(II). Interestingly, a recent study showed that structural Fe(II) in smectite was available as an electron donor to support autotrophic $\mathrm{Fe}(\mathrm{II})$ oxidation by $\mathrm{NO}_{3}{ }^{-}$(Shelobolina et al., 2003). The structural $\mathrm{Fe}$ (II) to $\mathrm{Fe}$ (III) conversions mediated by bacteria occurred without the Fe being detached from the smectite.

It was expected that blocking nitrate reductase with $\mathrm{WO}_{4}{ }^{2-}$ (high-N-W experiments) would isolate the contribution of the $\mathrm{Fe}$ (II)-oxidizing, $\mathrm{NO}_{3}{ }^{-}$-dependent autotrophic pathway. This would allow $\mathrm{Fe}$ (III) reduction to proceed and produce $\mathrm{Fe}(\mathrm{II})$, which then could participate in autotrophic $\mathrm{NO}_{3}{ }^{-}$reduction (Straub et al., 1996). As mentioned above, added $\mathrm{WO}_{4}{ }^{2-}$ affected $\mathrm{Fe}(\mathrm{III})$ reductase and may explain the discrepancy between $\mathrm{NO}_{3}{ }^{-}$reduced and $\mathrm{Fe}(\mathrm{II})$ oxidized in high-N-W slurries (Fig. 5b and 5d, Table 4). Past studies have shown that inhibitors such as $\mathrm{WO}_{4}{ }^{2-}$ have the potential to impact nontarget microorganisms when added to sediments (Oremland et al., 1989).

\section{SUMMARY AND CONCLUSIONS}

It has long been known that fertilizer $\mathrm{NO}_{3}{ }^{-}$applications to flooded soil can result in $\mathrm{N}$ loss through denitrification. Our results show that soil $\mathrm{Fe}(\mathrm{III})$ reduction can be hindered as well and may result in temporary changes in soil physicochemical properties if $\mathrm{NO}_{3}{ }^{-}$fertilizer is added to $\mathrm{Fe}(\mathrm{III})$-reducing soil. Addition of $\mathrm{NO}_{3}{ }^{-}$to soil under $\mathrm{Fe}$ (III)-reducing (anoxic) conditions inhibited $\mathrm{Fe}$ (II) production by preferential use of $\mathrm{NO}_{3}{ }^{-}$by nitrate reductase and anoxic $\mathrm{Fe}$ (II) oxidation. Processes that account for anoxic Fe(II) oxidation include concomitant $\mathrm{Fe}(\mathrm{III})$ and $\mathrm{NO}_{3}{ }^{-}$reduction coupled to reoxidation of $\mathrm{Fe}$ (II) by $\mathrm{NO}_{2}{ }^{-}$and $\mathrm{NO}_{3}{ }^{-}$-dependent, autotrophic $\mathrm{Fe}$ (II) oxidation. The role of these two processes in the inhibition in $\mathrm{Fe}(\mathrm{II})$ production became more important at high initial oxalate-extractable $\mathrm{Fe}$ (II) and $\mathrm{NO}_{3}{ }^{-}$concentrations. Thus, it may be important to consider the initial ratios of extractable $\mathrm{Fe}$ (II) to $\mathrm{NO}_{3}{ }^{-}$when trying to explain the mechanism of inhibition in $\mathrm{Fe}(\mathrm{II})$ production in anoxic soil environments. The inhibition was short-term in the sense that once $\mathrm{NO}_{3}{ }^{-}$was depleted, $\mathrm{Fe}(\mathrm{II})$ production resumed. An important consequence of $\mathrm{NO}_{3}{ }^{-}$-dependent $\mathrm{Fe}(\mathrm{II})$ oxidation is that the dissolved $\mathrm{Fe}(\mathrm{III})$ produced, even at micromolar levels, could behave as a kinetically labile oxidant.
It is difficult to separate the contributions of anoxic $\mathrm{Fe}(\mathrm{II})$ oxidation between $\mathrm{NO}_{3}{ }^{-}$-dependent, autotrophic $\mathrm{Fe}(\mathrm{II})$ oxidation and chemical reoxidation of $\mathrm{Fe}(\mathrm{II})$ by $\mathrm{NO}_{2}{ }^{-}$during concomitant $\mathrm{Fe}(\mathrm{III})$ and $\mathrm{NO}_{3}{ }^{-}$reduction on the basis of our data. One approach could include a prolonged incubation to exhaust microbially reducible $\mathrm{Fe}(\mathrm{III})$. Once $\mathrm{Fe}(\mathrm{II})$ production has stabilized, $\mathrm{NO}_{3}{ }^{-}$could be added to isolate $\mathrm{Fe}(\mathrm{II})$ oxidation. Perhaps addition of ferrozine to soil slurries to rapidly complex $\mathrm{Fe}(\mathrm{II})$ before $\mathrm{NO}_{2}{ }^{-}$oxidizes it would allow one to distinguish between chemical and biological processes. Furthermore, it would be interesting to follow $\mathrm{Fe}(\mathrm{II})$ and $\mathrm{Fe}$ (III) changes in the clay fraction to identify reactive species.

\section{ACKNOWLEDGMENTS}

This project was supported by National Research Initiative Competitive Grant no. 2002-35107-12214 from the USDA Cooperative State Research, Education, and Extension Service. We thank Larry Rice at ASTECC for assistance in SEM-EDS analysis and L.W. Murdock for help in acquiring the soil.

\section{REFERENCES}

Bard, A.J., R. Parsons, and J. Jordan. 1985. Standard potentials in aqueous solution. Marcel Dekker, New York.

Barnhisel, R.I., and P.M. Bertsch. 1989. Chlorites and hydroxyl-interlayered vermiculite and smecite. p. 729-788. In J.B. Dixon and S.B. Weed (ed.). Minerals in soil environments. 2nd ed. SSSA Book Ser. 1. Madison, WI.

Bowman, R.A., and D.D. Focht. 1974. The influence of glucose and nitrate concentrations upon denitrification rates in sandy soils. Soil Biol. Biochem. 6:297-301.

Bremner, J.M. 1996. Nitrogen-Total. p. 1085-1121. In D.L. Sparks (ed.) Methods of soil analysis. Part 3. SSSA Book Ser. 5. SSSA, Madison, WI.

Broholm, M.M., C. Crouzet, E. Arvin, and C. Mouvet. 2000. Concurrent nitrate and $\mathrm{Fe}(\mathrm{III})$ reduction during anaerobic biodegradation of phenols in a sandstone aquifer. J. Contam. Hydrol. 44:275-300.

Coates, J.D., D.J. Lonergan, H. Jenter, and D.R. Lovley. 1996. Isolation of Geobacter species from a variety of sedimentary environments. Appl. Environ. Microbiol. 62:1531-1536.

Cooper, D.C., F. Picardal, J. Rivera, and C. Talbot. 2000. Zinc immobilization and magnetite formation via ferric oxide reduction by Shewanella putrefaciens 200 . Environ. Sci. Technol. 34:100-106.

Cooper, D.C., F.W. Picardal, A. Schimmelmann, and A.J. Coby. 2003. Chemical and biological interactions during nitrate and goethite reduction by Shewanella putrefaciens 200. Appl. Environ. Microbiol. 69:3517-3525.

DiChristina, T.J. 1992. Effects of nitrate and nitrite on dissimilatory iron reduction by Shewanella putrefaciens 200. J. Bacteriol. 174:1891-1896.

Favre, F., D. Tessier, M. Abdelmoula, J.M. Génin, W.P. Gates, and P. Boivin. 2002. Iron reduction and changes in cation exchange capacity in intermittently waterlogged soil. Eur. J. Soil Sci. 53:175-183.

Fredrickson, J.K., J.M. Zachara, D.W. Kennedy, H. Dong, T.C. Onstott, N.W. Hinman, and S. Li. 1998. Biogenic iron mineralization accompanying the dissimilatory reduction of hydrous ferric oxide by a groundwater bacterium. Geochim. Cosmochim. Acta 62:3239-3257.

Hille, R. 1996. The mononuclear molybdenum enzymes. Chem. Rev. 96:2757-2816.

Hyacinthe, C., P. Anschutz, P. Carbonel, J.M. Jouanneau, and F.J. Jorrisen. 2001. Early diagenetic processes in the muddy sediments of the Bay of Biscay. Mar. Geol. 177:111-128.

Jackson, M.L. 1974. Soil chemical analysis-Advanced course. M.L. Jackson, Madison, WI.

Karathanasis, A.D. 1987. Mineral solubility relationships in Fragiudalfs of western Kentucky. Soil Sci. Soc. Am. J. 51:474-481.

Klüber, H.D., and R. Conrad. 1998. Effects of nitrate, nitrite, $\mathrm{NO}$, and $\mathrm{N}_{2} \mathrm{O}$ on methanogenesis and other redox processes in anoxic rice field soil. FEMS Microbiol. Ecol. 25:301-318.

Kohl, D.H., F. Vithayathil, P. Whitlow, G. Shearer, and S.H. Chien. 1976. Denitrification kinetics in soil systems: The significance of good fits of data to mathematical forms. Soil Sci. Soc. Am. J. 40:249-253. 
Komadel, P., P.R. Lear, and J.W. Stucki. 1990. Reduction and reoxidation of nontronite: Extent of reduction and reaction rates. Clays Clay Miner. 38:203-208.

Komatsu, Y., M. Takagi, and M. Yamaguchi. 1978. Participation of iron in denitrification in waterlogged soil. Soil Biol. Biochem. 10:21-26.

Krause, B., and K.H. Nealson. 1997. Physiology and enzymology involved in denitrification by Shewanella putrefaciens. Appl. Environ. Microbiol. 63:2613-2618.

Kukkadapu, R.K., J.M. Zachara, S.C. Smith, J.K. Fredrickson, and C. Liu. 2001. Dissimilatory bacterial reduction of $\mathrm{Al}$-substituted goethite in subsurface sediments. Geochim. Cosmochim. Acta 65:2913-2924.

Lovley, D.R. 2000. Fe(III) and Mn(IV) reduction. p. 3-30. In D.R. Lovley (ed.) Environmental microbe-metal interactions. ASM Press, Washington, DC.

Luther, G.W., III, J.E. Kostka, T.M. Church, B. Sulzberger, and W. Stumm. 1992. Seasonal iron cycling in the salt marsh sedimentary environment-The importance of ligand complexes with $\mathrm{Fe}(\mathrm{II})$ and $\mathrm{Fe}(\mathrm{III})$ in the dissolution of $\mathrm{Fe}(\mathrm{III})$ minerals and pyrite, respectively. Mar. Chem. 40:81-103.

McBride, M.B. 1994. Environmental chemistry of soils. Oxford Univ. Press, New York.

Mehra, O.P., and M.L. Jackson. 1960. Iron oxide removal from soils and clays by a dithionite-citrate system buffered with sodium bicarbonate. Clays Clay Miner. 7:317-327.

Munch, J.C., and J.C.G. Ottow. 1980. Preferential reduction of amorphous to crystalline iron oxides by bacterial activity. Soil Sci. 129:15-21.

Murillo, F.M., T. Gugliuzza, J. Senko, P. Basu, and J.F. Stolz. 1999. A heme-Ccontaining enzyme complex that exhibits nitrate and nitrite reductase activity from the dissimilatory iron-reducing bacterium Geobacter metallireducens. Arch. Microbiol. 172:313-320.

Nelson, D.W., and L.E. Sommers. 1996. Total carbon, organic carbon, and organic matter. p. 961-1010. In D.L. Sparks (ed.) Methods of soil analysis. Part 3. SSSA Book Ser. 5. SSSA, Madison, WI.

Nielsen, J.L., and P.H. Nielsen. 1998. Microbial nitrate-dependent oxidation of ferrous iron in activated sludge. Environ. Sci. Technol. 32:3556-3561.

Obuekwe, C.D., D.W.S. Westlake, and F.D. Cook. 1981. Effect of nitrate on reduction of ferric iron by a bacterium isolated from crude oil. Can. J. Microbiol. 27:692-697.

Oremland, R.S., J.T. Hollibaugh, A.S. Maest, T.S. Presser, L.G. Miller, and C.W. Culbertson. 1989. Selenate reduction to elemental selenium by anaerobic bacteria in sediments and culture: Biogeochemical significance of a novel, sulfate-independent respiration. Appl. Environ. Microbiol. 55:2333-2343.

Ottow, J.C.G. 1970. Selection, characterization, and iron-reducing capacity of nitrate reductaseless $\left(\right.$ nit $\left.^{-}\right)$mutants from iron-reducing bacteria. Z. Allg. Mikrobiol. 8:441-443.

Patrick, W.H., R.P. Gambrell, and S.P. Faulkner. 1996. Redox measurements of soils. p. 1255-1273. In D.L. Sparks (ed.) Methods of soil analysis. Part 3. SSSA Book Ser. 5. SSSA, Madison, WI.

Phillips, E.J.P., and D.R. Lovley. 1987. Determination of Fe(III) and Fe(II) in oxalate extracts of sediment. Soil Sci. Soc. Am. J. 51:938-941.

Ponnamperuma, F.N. 1972. The chemistry of submerged soils. Adv. Agron. 24:29-96.

Ponnamperuma, F.N., and R.U. Castro. 1964. Redox systems in submerged soils. Int. Congr. Soil Sci. Trans. 8:379-386.

Roden, E.E. 2003. Fe(III) oxide reactivity toward biological versus chemical reduction. Environ. Sci. Technol. 37:1319-1324.

Roth, C.B., M.L. Jackson, and J.K. Syers. 1969. Deferration effect on structural ferrous-ferric iron ratio and CEC of vermiculites and soils. Clays Clay Miner. 17:253-264.

Schecher, W. 1998. MINEQL+ Version 4.5. Environ. Res. Software, Hallowell, ME.

Schwertmann, U., and R.M. Cornell. 1991. Iron oxides in the laboratory: Preparation and characterization. Wiley-VEH, New York.

Scott, R.H., G.T. Sperl, and J.A. DeMoss. 1979. In vitro incorporation of molybdate into demolybdoproteins in Escherichia coli. J. Bacteriol. 137:719-726.

Senko, J.M., and J.F. Stolz. 2001. Evidence for iron-dependent nitrate respiration in the dissimilatory iron-reducing bacterium. Appl. Environ. Microbiol. 67:3750-3752.

Senn, D.B., and H.F. Hemond. 2002. Nitrate controls on iron and arsenic in an urban lake. Science 296:2373-2376.

Shelobolina, E.S., C.G. Vanpraagh, and D.R. Lovley. 2003. Use of ferric and ferrous iron containing minerals for respiration by Desulfitobacterium frappieri. Geomicrobiol. J. 20:143-156.

Shriver, D.F., P. Atkins, and C.H. Langford. 1994. Inorganic chemistry. W.H. Freeman and Co., New York.

Smith, M.S. 1983. Nitrous oxide production by Escherichia coli is correlated with nitrate reductase activity. Appl. Environ. Microbiol. 45:1545-1547.

Sorensen, J. 1982. Reduction of ferric iron in anaerobic, marine sediment and interaction with reduction of nitrate and sulfate. Appl. Environ. Microbiol. 43:319-324.

Sorensen, J., and L. Thorling. 1991. Stimulation by lepidocrocite $(\gamma-\mathrm{FeOOH})$ of $\mathrm{Fe}(\mathrm{II})$-dependent nitrite reduction. Geochim. Cosmochim. Acta 55:1289-1294.

Stookey, L.L. 1970. Ferrozine-A new spectrophotometric reagent for iron. Anal. Chem. 42:779-781.

Straub, K.L., M. Benz, B. Schink, and F. Widdel. 1996. Anaerobic, nitratedependent microbial oxidation of ferrous iron. Appl. Environ. Microbiol. 62:1458-1460.

Stucki, J.W., G.W. Bailey, and H.M. Gan. 1996. Oxidation-reduction mechanisms in iron-bearing phyllosilicates. Appl. Clay Sci. 10:417-430.

Suess, E. 1979. Mineral phases formed in anoxic sediments by microbial decomposition of organic matter. Geochim. Cosmochim. Acta 43:339-352.

Tratnyek, P.G., and N.L. Wolfe. 1993. Oxidation and acidification of anaerobic sediment-water systems by autoclaving. J. Environ. Qual. 22:375-378.

Van Bodegom, P.M., J.V. Reeven, and H.A.C. Denier Van Der Gon. 2003. Prediction of reducible soil iron content from iron extraction data. Biogeochemistry 64:231-245.

Van Cleemput, O., and L. Baert. 1983. Nitrite stability influenced by iron compounds. Soil Biol. Biochem. 15:137-140.

Weatherburn, M.W. 1967. Phenol-hypochlorite reaction for determination of ammonia. Anal. Chem. 39:971-974.

Weber, K.A., F.W. Picardal, and E.E. Roden. 2001. Microbially-catalyzed nitratedependent oxidation of biogenic solid phase Fe(II) compounds. Environ. Sci. Technol. 35:1644-1650.

Wehrli, B. 1990. Redox reactions of metal ions at mineral surfaces. p. 311-336. In W. Stumm (ed.) Aquatic chemical kinetics. John Wiley \& Sons, New York.

Zachara, J.M., R.K. Kukkadapu, J.K. Fredrickson, Y.A. Gorby, and S.C. Smith. 2002. Biomineralization of poorly crystalline Fe(III) oxides by dissimilatory metal reducing bacteria (DMRB). Geomicrobiol. J. 19:179-207. 